\title{
Application of an intragenic genomic probe to genetic counselling for haemophilia $B$ in the west of Scotland
}

\author{
J M CONNOR*, A F PETTIGREW $\dagger$, I M HANN $\dagger$, C D FORBES $\dagger$, G D O LOWE $\dagger$, \\ AND N A AFFARA* \\ From * the Department of Medical Genetics and the Department of Haematology, University of Glasgow, \\ Glasgow.
}

SUMmARY Total ascertainment revealed 28 families with haemophilia B in the west of Scotland (prevalence 1/26 870 males). In 12 of these families more than one person was affected and 26 living obligate carriers were identified and tested. Of these, $42 \%$ were heterozygous for a DNA polymorphism recognised by a factor IX genomic probe. No recombination was observed in 11 phase known and four phase unknown informative meioses. Definitive genetic counselling was possible for 14 of 42 females at risk, 11 could not be traced, in 10 the probe was not informative, and in seven paternal absence prevented interpretation. Linkage disequilibrium was apparent for this restriction fragment length polymorphism and haemophilia B in the west of Scotland.

The principal difficulties in genetic counselling of families with haemophilia B (Christmas disease, factor IX deficiency) relate to detection of female carriers and early prenatal diagnosis of affected males. Levels of factor IX coagulant activity (IX:C) have a wide normal range (60 to $160 \%$ ) and serial assays in a single person can vary considerably. ${ }^{1}$ Measurement of factor IX coagulant activity alone can confidently identify fewer than $50 \%$ of obligate carriers. ${ }^{2}$ Simultaneous immunoradiometric assay of the level of factor IX antigen (IX:Ag) improves detection of obligate carriers to $90 \%$ in the less common CRM positive variants of haemophilia B, but only increases the detection level to $56 \%$ in the CRM negative variants. ${ }^{3}$ The carrier likelihood from these assays can be combined with pedigree information using Bayes's theorem. ${ }^{4}$ Prenatal diagnosis is possible after fetal blood sampling in male pregnancies but has the disadvantages of a significant fetal mortality and, if positive, a late termination of pregnancy. ${ }^{56}$

A recombinant DNA approach to these difficulties became possible with the isolation of the human factor IX gene and the characterisation of a frequent intragenic polymorphic marker. ${ }^{7-9}$ We report our experience in the west of Scotland using this probe

Received for publication 8 February 1985. Accepted for publication 18 February 1985. for genetic counselling of families with haemophilia B.

\section{Subjects and methods}

Patients with haemophilia B were identified from the records of the Regional Haemophilia Reference Centre at the Glasgow Royal Infirmary and the Royal Hospital for Sick Children, Glasgow, and from the genetic register of the West of Scotland Regional Genetics Service. An extended pedigree was obtained and blood samples were taken for DNA analysis and coagulation studies.

DNA was extracted using the method of Kunkel et al. ${ }^{10}$ The DNA fragments produced by digestion with the restriction enzyme TaqI were separated by electrophoresis in $0.8 \%$ agarose gel and transferred to nitrocellulose filters (Schleicher and Schüll) by Southern blotting. ${ }^{11}$ Probe VIII is a $2.5 \mathrm{~kb}$ segment of the factor IX gene comprising $2.4 \mathrm{~kb}$ of introns and the ' $d$ ' exon. ${ }^{2}$ This probe was labelled with ${ }^{32} \mathrm{P}$ by nick translation. ${ }^{13}$ Hybridisation was carried out at $42^{\circ} \mathrm{C}$ in $50 \%$ formamide, $1 \times$ Denhardts solution, $5 \times \mathrm{SSC}, 20 \mathrm{mmol} / 1 \mathrm{NaH}_{2} \mathrm{PO}_{4}(\mathrm{pH} 6 \cdot 8), 0 \cdot 1 \mathrm{mg} / \mathrm{ml}$ heat denatured salmon sperm DNA, $20 \mathrm{~g} / \mathrm{ml}$ poly $\mathrm{A}$, and $10 \%$ dextran sulphate. After hybridisation, excess probe was removed by washing twice in $1 \times \mathrm{SSC}, 0 \cdot 1 \%$ sodium dodecylsulphate (SDS) at room temperature for 20 minutes, followed by one 
or two washes in $0.1 \times$ SSC, $0.1 \%$ SDS for 30 minutes at $63^{\circ} \mathrm{C}$. DNA bands were detected by autoradiography with $x$-ray film and intensifying screens.

\section{Results}

Probe VIII identifies two bands in blots of DNA from males and two or three bands in blots of DNA from females (fig 1). The $5.3 \mathrm{~kb}$ band occurred in all subjects. In male subjects the second band was either $1.8 \mathrm{~kb}$ or $1.3 \mathrm{~kb}$. The $500 \mathrm{bp}$ fragment cleaved in the production of the $1.3 \mathrm{~kb}$ fragment is not visualised. Females were heterozygous $(1 \cdot 8 / 1 \cdot 3 \mathrm{~kb})$ or homozygous for either fragment. In the unrelated Scottish subjects (six males and 20 females) the frequency of the $1.8 \mathrm{~kb}$ fragment was 0.63 (29 of $46 \mathrm{X}$ chromosomes) and of the $1.3 \mathrm{~kb}$ fragment 0.37 (17 of $46 \mathrm{X}$ chromosomes).

Fifty-two males with haemophilia B were identified with an age range of 2 to 76 years. This represents a prevalence of 1 in 26870 males.

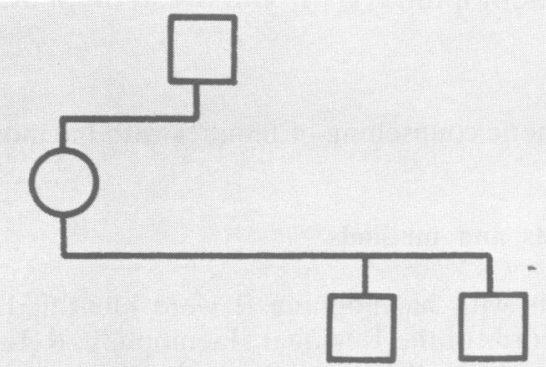

$\mathrm{kb}$

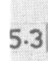

1.8

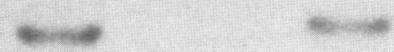

1.3

FIG $1 X$ chromosomal restriction fragment length polymorphism revealed by hybridisation to probe VIII after TaqI digestion.
Initially these were considered to belong to 35 separate families but extended pedigrees revealed that several were related. Of the remaining 28 families, 16 contained only a single affected male and 12 had two or more affected subjects. Three of these 12 families refused to cooperate but the pedigrees and results of the others are shown in figs 2 to 10 .

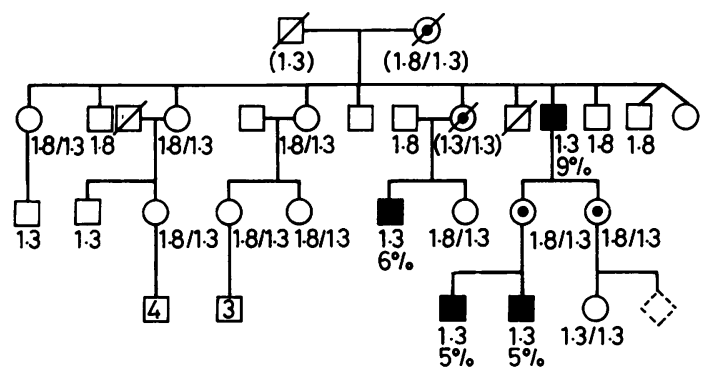

FIG 2-10 Pedigrees of familial cases of haemophilia $B$ in the west of Scotland. Probe VIII/TaqI restriction fragment pattern $(1.8 \mathrm{~kb}, 1.3 \mathrm{~kb})$ is indicated for each subject as is the level of factor IX activity in certain subjects.

FIG 2 Pedigree 1756.

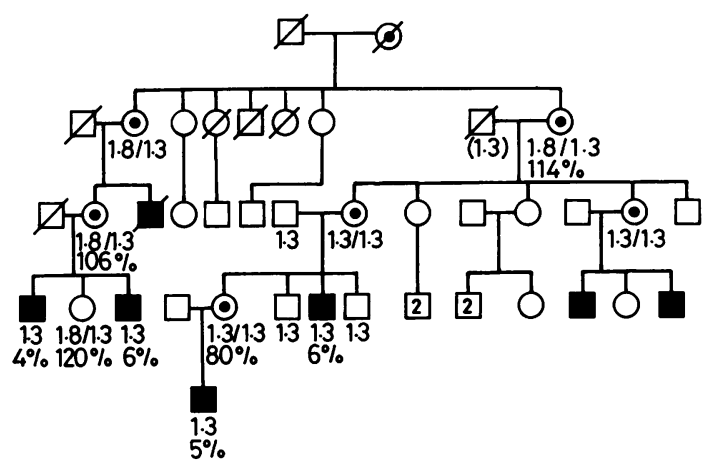

FIG 3 Pedigree 2377.

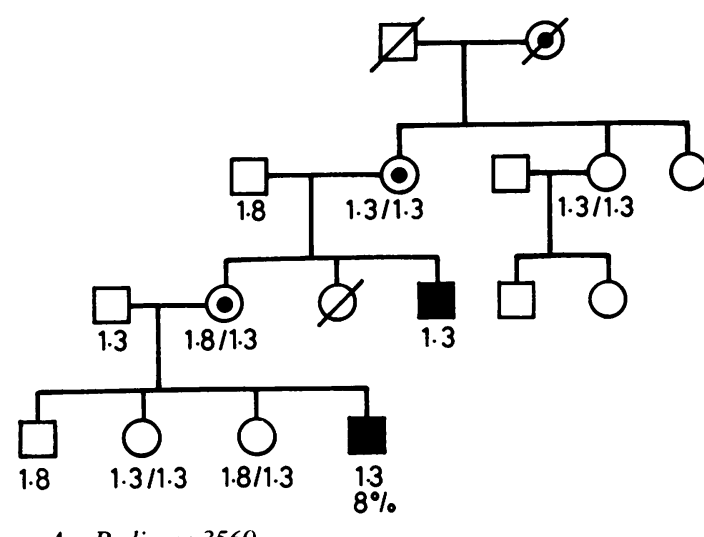

FIG 4 Pedigree 3569. 
These nine families contained 29 living obligate carriers and 26 of these were traced and tested. Eleven $(42 \%)$ were heterozygous $(1 \cdot 8 / 1 \cdot 3)$ for probe VIII and thus potentially informative; 14 were homozygous for the $1.3 \mathrm{~kb}$ fragment and one was homozygous for the $1.8 \mathrm{~kb}$ fragment. Levels of factor IX activity were measured in eight obligate carriers and only one had a value $(58 \%)$ outside the normal range.

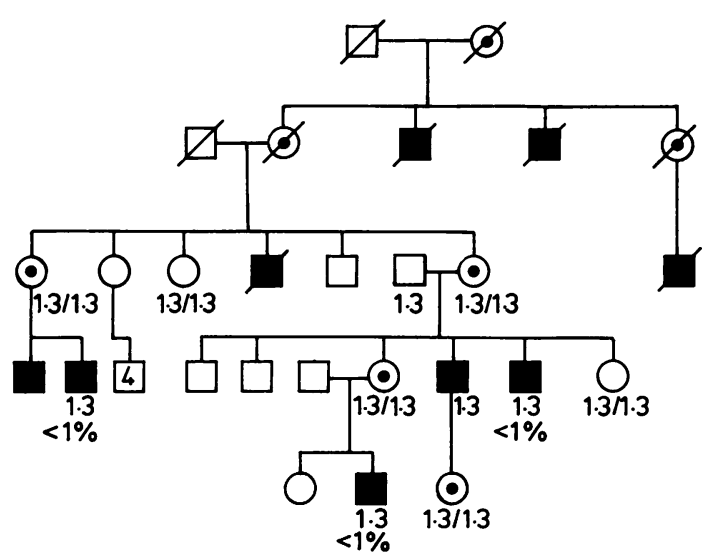

FIG 5 Pedigree 4542 .

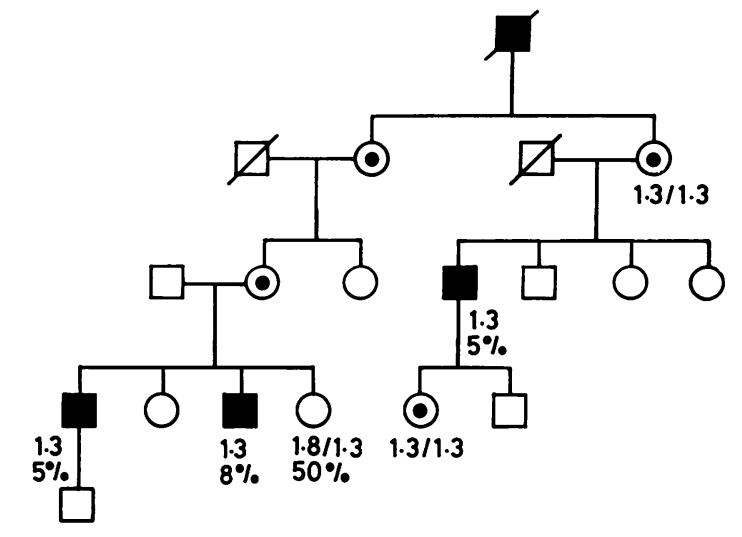

FIG 8 Pedigree 4555 .

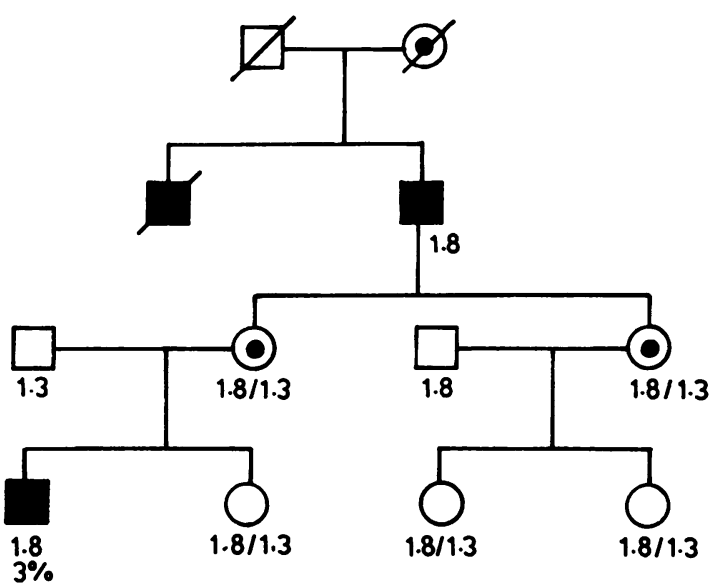

FIG 9 Pedigree 4559

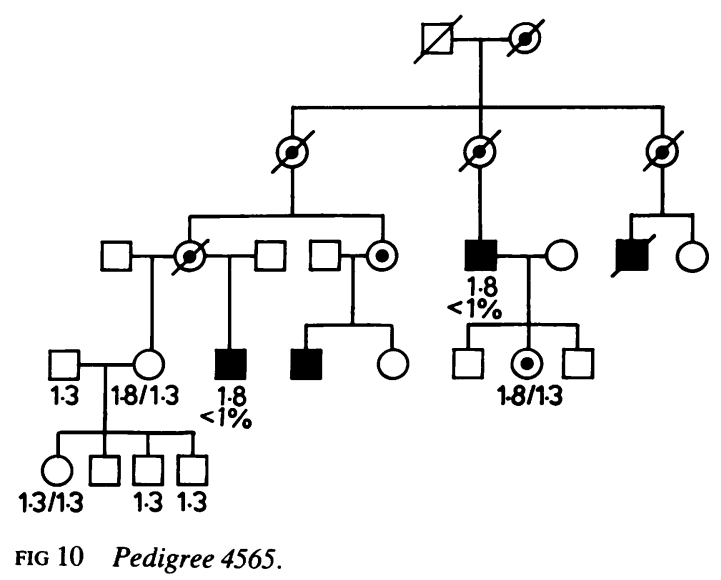

FIG 7 Pedigree 4551.

FIG 10 Pedigree 4565. 
TABLE 1 DNA results for females at risk of haemophilia $B$.

\begin{tabular}{llccc}
\hline & $\begin{array}{l}\text { Obligate } \\
\text { carrier* }\end{array}$ & $\begin{array}{l}\text { Not a } \\
\text { carrier }\end{array}$ & $\begin{array}{l}\text { Not } \\
\text { informative }\end{array}$ & $\begin{array}{l}\text { Fot } \\
\text { available } \\
\text { traced }\end{array}$ \\
\hline Family contemplated & 4 & 7 & $7+$ & 7 \\
Family completed & - & 3 & 3 & -5 \\
Total & 4 & 10 & 10 & 7 \\
\hline
\end{tabular}

${ }^{*}$ Excluding intragenic recombination.

IIn two cases the fathers were also unavailable.

TABLE 2 DNA results in familial cases of haemophilia $B$.

\begin{tabular}{lcl}
\hline Family & $\begin{array}{l}\text { Average factor } \\
\text { IX level in } \\
\text { affected males }(\%)\end{array}$ & $\begin{array}{l}\text { RFLP fragment } \\
\text { linked to the } \\
\text { mutant factor IX } \\
\text { allele }(\mathrm{kb})\end{array}$ \\
\hline 4542 & & $1 \cdot 3$ \\
1756 & $<1$ & $1 \cdot 3$ \\
4555 & 6 & $1 \cdot 3$ \\
2377 & 6 & $1 \cdot 3$ \\
3569 & 8 & $1 \cdot 3$ \\
4549 & 8 & $1 \cdot 3$ \\
4565 & 22 & $1 \cdot 8$ \\
4559 & $<1$ & $1 \cdot 8$ \\
4551 & 3 & $1 \cdot 8$ \\
\hline
\end{tabular}

Forty-two females at risk were identified. Each had a pedigree risk of greater than or equal to 1 in 4 . Thirty-one of these females were traced and tested and the results are summarised in table 1 and subdivided according to whether or not family extension was contemplated.

No recombination was observed in 11 phase known informative meioses and four phase unknown meioses.

In six of these nine families haemophilia B was segregating with the less frequent $1.3 \mathrm{~kb}$ restriction fragment (table 2). From the RFLP frequencies in the general population only three of these families would have been expected to have the mutant factor IX allele linked to the $1.3 \mathrm{~kb}$ restriction fragment. This difference is statistically significant $\left(\chi^{2}=4 \cdot 5\right.$, $\mathrm{p}<0.05)$.

\section{Discussion}

Haemophilia B shows marked genetic heterogeneity but in all of these variants the primary defect is a reduction in factor IX activity. Thus a polymorphic intragenic probe from the factor IX gene is the ideal marker for the mutant allele. Gianelli $e^{2} a l^{8}$ used such a marker (probe VIII) in three families segregating for haemophilia B and observed no recombination. However, these families only included three phase known informative meioses. In nine families from the west of Scotland no recombination was observed in 15 further opportunities for recombination.

Gianelli et $a l^{8}$ predicted that the polymorphism detected by probe VIII would be helpful in genetic counselling of about $40 \%$ of affected families on the basis of the expected heterozygote frequency. We found a similar frequency for this RFLP in the west of Scotland and the probe was informative for $42 \%$ (11 of 26) obligate carrier females (table 3). Although the heterozygote frequency was close to that predicted from the Hardy-Weinberg equilibrium, the homozygote frequencies for this RFLP were disturbed by linkage disequilibrium.

In our families, 14 of $31(45 \%)$ females at high risk could be definitively counselled using this single polymorphic probe. Non-informative matings prevented counselling of 10 and paternal absence prevented counselling of seven females at risk. Both of these problems could be circumvented by applying other intragenic or closely linked RFLPs to produce a haplotype for the mutant allele. ${ }^{15}$

There is increasing evidence for heterogeneity among families with haemophilia B. For example, Parekh et $\mathbf{~}^{16}$ in a multicentre study of 98 families found 52 to be CRM negative, 30 to be CRM reduced, and 16 to have CRM levels above or equal to those expected from their levels of factor IX coagulant activity. Gene deletions of variable size

TABLE 3 Frequencies of the restriction fragment length polymorphism detected by probe VIII after TaqI digestion.

\begin{tabular}{llll}
\hline $\begin{array}{l}\text { RFLP fragment } \\
\text { frequencies }\end{array}$ & $\begin{array}{l}\text { Number of } X \\
\text { chromosomes } \\
\text { analysed }\end{array}$ & Study \\
\hline $1.8 \mathrm{~kb}$ & $1.3 \mathrm{~kb}$ & & \\
\hline 0.65 & 0.35 & 45 & Gianelli et al \\
0.635 & 0.365 & 63 & Choo et al \\
0.63 & 0.37 & 46 & Present study \\
\hline
\end{tabular}


have been demonstrated in five of the six known British haemophilia B patients who have factor IX antibodies. ${ }^{12}{ }^{17}$ In patients without gene deletions the clinical and haematological evidence for heterogeneity would suggest a wide variety of molecular pathology, yet for all subjects the linked RFLP approach to carrier detection and prenatal diagnosis would be applicable.

Although prenatal diagnosis of haemophilia B has been possible after fetoscopic blood sampling since 1979 , only about one third of females at risk use this procedure. ${ }^{18} 19$ However, in each of these studies most women had limited their families in view of the risk. First trimester prenatal diagnosis of haemophilia B is now feasible with sexing and DNA diagnosis on chorion biopsy material for phase known mothers, and it might be expected that the proportion of mothers at risk who use prenatal diagnosis will increase.

Edwards ${ }^{20}$ has estimated that a DNA segment 100 $\mathrm{kb}$ long has only a $50 \%$ chance of rearrangement in 700 generations or about 20000 years. Hence, any haemmphilia B family, even if extensive, will show non-random association or linkage disequilibrium for this intragenic RFLP and the disease mutation. However, linkage disequilibrium at a population level for haemophilia B and this intragenic RFLP would not be expected. Indeed, overall, the proportions of families with linkage to each RFLP fragment should reflect the individual fragment frequencies. In the west of Scotland there is a statistically significant departure from the expected ratio with most families demonstrating linkage to the less frequent $1.3 \mathrm{~kb}$ fragment. This is probably due to chance, but an alternative explanation might be that some of these families are distantly related, especially those with similar levels of factor IX activity (table 2). This would be supported by finding an identical haplotype for several intragenic RFLPs in related families. Linkage disequilibrium is of practical importance as it will either increase or decrease the predicted value of a linked marker according to whether the disease is linked to the less frequent or more frequent allele. ${ }^{21}$

Thus a single polymorphic intragenic marker can help a substantial number of females at risk in families with haemophilia B. If technical problems such as confusion of samples and partial digestion are excluded then the only sources of error are intragenic recombination and disease due to a non-syntenic regulator mutation. The latter can be excluded by typing informative family members and the former is estimated to occur with a frequency of only 1 in 5000 to 10000 for a recognition site 10 to $20 \mathrm{~kb}$ from the disease mutation. ${ }^{22}$ Linkage disequilibrium, non-information, and paternal absence are important limitations both for this and other similar studies, but despite these this study has demonstrated the practical value of this approach to genetic counselling for a single gene disorder.

We wish to thank Professor G G Brownlee for supplying probe VIII. This study was supported in part by grants from the Wellcome Trust and the National Fund for Research into Crippling Diseases.

\section{References}

I Kasper CK, Osterud B, Minami JY, Shonick W, Rapaport SI. Haemophilia B: characterisation of genetic variants and detection of carriers. Blood 1977;50:351-66.

2 Simpson NE, Biggs R. The inheritance of Christmas factor. $\mathrm{Br}$ J Haematol 1962:8:191-203.

3 Orstavik KH, Veltkamp JJ, Bertini RM, Hermans J. Detection of carriers of haemophilia B. Br J Haematol 1979;42:293-301.

4 Graham JB, Barrow ES, Reisner HM, Edgell CJS. The genetics of blood coagulation. In: Harris $\mathrm{H}$, Hirschhorn K, eds. Advances in human genetics. Vol 13. New York, London: Plenum, 1983:1-82.

5 Mibashan RS, Rodeck CH. Thumpston JK, et al. Plasma assay of fetal factors VIIIc and IX for prenatal diagnosis of haemophilia. Lancet 1979:i:1309-11.

6 Holmberg L. Gustavii B, Cordesius E. et al. Prenatal diagnosis of haemophilia B by an immunoradiometric assay of factor IX. Blood 1980;56:397-401.

7 Choo KH, Gould KG. Rees DJG. Brownlec GG. Molecular cloning of the gene for human anti-haemophilic factor IX. Nature 1982;299:178-80.

$\times$ Gianelli F, Anson DS, Choo KH, et al. Characterisation and use of an intragenic polymorphic marker for the detection of carriers of haemophilia B (factor IX deficiency). Lancet 1984;i:239-41.

9 Anson DS. Choo KH. Rees DJG, et al. The gene structure of human anti-hacmophilic factor IX. EMBO J 1984;3:1053-60.

10 Kunkel LM, Smith KD, Boyer SH, et al. Analysis of human Y-chromosome specific reiterated DNA in chromosome variants. Proc Natl Acad Sci USA 1977;74:1245-9.

1 Southern EM. Detection of specific sequences among DNA fragments separated by gel electrophoresis. J Mol Biol 1975;98:503-17.

12 Gianelli F, Choo KH, Rees DJG, Boyd Y, Rizza CR, Brownlee GG. Gene deletions in patients with haemophilia $B$ and anti-factor IX antibodies. Nature 1983;303:181-2.

13 Rigby PWJ, Dieckmann M, Rhodes C, Berg P. Labelling DNA to high specific activity by in vitro nick translation with DNA polymerase. J Mol Biol 1977;113:237-51.

14 Choo KH, George D, Filby G, et al. Linkage analysis of $\mathrm{X}$-linked mental retardation with and without fragile $\mathrm{X}$ using factor IX gene probe. Lancet 1984;ii:349.

15 Winship PR, Anson DS, Rizza CR, Brownlee GG. Carrier detection in haemophilia $B$ using 2 further intragenic restriction fragment length polymorphisms. Nucleic Acids Res 1984;12:8861-72.

16 Parekh VR, Mannucci PM, Ruggeri ZM. Immunological heterogeneity of haemophilia B: a multicentre study of 98 kindreds. Br J Haematol 1978;40:643-55.

17 Peake IR, Furlong BL, Bloom AL. Carrier detection by direct gene analysis in a family with haemophilia B (factor IX deficiency). Lancet 1984;i:242-3.

18 Evans DIK. Shaw A. Attitudes of haemophilia carriers to fetoscopy and amniocentesis. Lancet 1979;ii:1371. 
19 Markova I, Forbes CD, Inwood M. The consumers' views of genetic counselling in hemophilia. Am J Med Genet 1984;17:741-52.

20 Edwards JH. Population genetics of $\mathrm{C} 4$ with the use of complementary DNA probes. Philos Trans $R$ Soc Lond (Biol) 1984;306:405-17.

21 Chakravarti A. Utility and efficiency of linked marker genes for genetic counselling. III. Proportion of informative families

under linkage disequilibrium. Am J Hum Genet 1983;35:592610.

22 Kurnit DM, Hoehn H. Prenatal diagnosis of human genome variation. Ann Rev Genet 1979;13:235-58.

Correspondence and requests for reprints to Dr J M Connor, Duncan Guthrie Institute of Medical Genetics, Yorkhill, Glasgow G3 8SJ. 